\title{
Histochemical Demonstration of Certain Hydrolytic Enzymes within Cytoplasmic Particles of Botrytis cinerea Fr.
}

\author{
By D. PITT \\ Department of Botany, University of Exeter \\ (Accepted for publication 17 November 1967)
}

SUMMARY

\begin{abstract}
Established histochemical methods were used to locate the activities of several acid and neutral hydrolases within cytoplasmic particles of Botrytis cinerea Fr. The Gomori procedure revealed acid phosphatase activity and this was used as a marker to show that these particles in fresh material were inactive until subjected to treatments which affected the permeability of lipid-protein membranes. This behaviour was interpreted as indicating that these particles may be comparable with the lysosomes of animal cells. It was shown that acid phosphatase, acid deoxyribonuclease II, $\beta$-galactosidase and several esterases were localized within these particles. Attempts to demonstrate $\beta$-D-glucuronidase activity were unsuccessful; aryl sulphatase activity was weak.
\end{abstract}

\section{INTRODUCTION}

It is considered that acid phosphatase activity in fungi is localized within cytoplasmic particles (Novikoff, I96I ; Pitt \& Walker, 1967). It is also believed (de Duve, 1959) that the lysosomes of animal cells contain all the cytoplasmic acid phosphatase and are rich in other hydrolases. Pitt \& Walker (1967) showed lysosomal properties in cytoplasmic particles of several fungi, and Zalokar (1960) showed the distribution of acid phosphatase within the mitochondrial fraction of freeze-substituted centrifuged hyphae. However, the evidence for the existence of lysosomes in fungi is incomplete. The present work was designed to examine the distribution of some acid and neutral hydrolases in Botrytis cinerea and to determine whether these enzymes are localized in particles having affinities with the lysosomes of cells of animals and higher plants.

\section{METHODS}

A strain of Botrytis cinerea (DM 32), newly isolated from rotting anemone leaves, was grown on coverslips for 3 days at $25^{\circ}$ on discs of malt extract agar according to Ridell (I950). The discs were removed and the tissue adhering to the coverslips was used directly or after appropriate fixation.

Histochemical methods. These generally were established procedures with modifications as indicated. Fixation, unless otherwise stated, was in Baker's formol-calcium fixative for $16 \mathrm{hr}$ at $0-4^{\circ}$.

Acid phosphatase. (a) The Gomori (1952) lead nitrate method was used for fresh and fixed tissues with incubation for I-60 min. depending upon experimental procedure. Latency of enzyme activity was examined by the methods of Gahan (1965) and included pre-incubation in $4 \%(\mathrm{w} / \mathrm{v})$ aqueous formaldehyde solution, in buffers and in aqueous 
Triton X-I0o. (b) The standard coupling azo dye technique (Grogg \& Pearse, I952) with sodium $\alpha$-naphthylphosphate and Fast garnet GBC salt (G. T. Gurr, Ltd.) and incubation times of $20-30 \mathrm{~min}$. at $37^{\circ}$ was done, with and without osmotic protection provided by $7.5 \%$ polyvinyl pyrrolidone in the medium. (c) The post-coupling azo dye method (Rutenberg \& Seligman, 1955) was used for fixed tissues with sodium 6-benzoyl-2-napththylphosphate with incubation for $\mathrm{I}$ hr at $37^{\circ}$ followed by coupling with Fast blue B salt (G. T. Gurr, Ltd.) at $0^{\circ}$. Appropriate controls were: (i) incubation without substrates; (ii) incubation in the presence of $10^{-2} \mathrm{M}$-sodium fluoride; (iii) with tissues heated in free steam for $5 \mathrm{~min}$.; (iv) omission of ammonium sulphide (Gomori) or the coupling dyes.

Esterases. (a) Holt's indoxyl method (Holt, 1958) was applied to fixed tissue with O-acetyl-5-bromoindoxyl (K and K Laboratories Inc., New York) and an incubation time of $30 \mathrm{~min}$. at $22^{\circ}$. Appropriate controls were used and the effects of known esterase inhibitors examined. Tissues were incubated for $\mathrm{I}-4 \mathrm{hr}$ in diethyl-p-nitrophenyl phosphate $(E 600)$ at $\mathrm{IO}^{-3}, \mathrm{IO}^{-5}, \mathrm{IO}^{-7}$ and $10^{-9} \mathrm{M}$ in $0.05 \mathrm{M}$-acetate buffer $\left(\mathrm{pH} \mathrm{6.0)}\right.$ at $22^{\circ}$, and in $5 \times 10^{-3} \mathrm{M}$-iodoacetamide in tris $\mathrm{HCl}$ buffer $(0 . \mathrm{I} \mathrm{M}, \mathrm{pH} 7 \cdot 0)$ and in $0 . \mathrm{I} \mathrm{M}$ - $N$-ethylmaleimide in similar buffer before incubation in the indoxyl medium for the usual time. (b) Substituted coupling azo-dye methods. The modified $\alpha$-naphthylacetate method of Nachlas \& Seligman (1949) was done on fresh tissues with incubation for $10 \mathrm{~min}$. in the presence of Fast blue B salt at $22^{\circ}$. The Davis \& Ornstein (1959) modification with 'hexazotized' $p$-rosaniline as the coupling dye was also used with fixed and fresh tissues, with incubation for $20 \mathrm{~min}$. at $22^{\circ}$. The method of Gomori (1952) was used with naphthol-AS acetate as the substrate and Fast red RC salt (G. T. Gurr, Ltd.) as the coupling dye under conditions mentioned below. These azo dye methods were also performed after incubation in appropriate buffer at $22^{\circ}$ containing $E 600$ at $1^{1} \mathrm{O}^{-3}, \mathrm{IO}^{-5}$ and $\mathrm{IO}^{-7} \mathrm{M}$. (c) Thioacetic acid method (Wachstein, Meisel \& Falcon, 196r) was done on fresh and fixed tissues with incubation for $\mathrm{I}-\mathrm{I} \frac{1}{2} \mathrm{hr}$ at $22^{\circ}$. The effect on staining of incubation for $\mathrm{I} \mathrm{hr}$ at $22^{\circ}$ in $\mathrm{IO}^{-3}, \mathrm{IO}^{-5}$, $\mathrm{IO}^{-7}$ and $\mathrm{IO}^{-9} \mathrm{M}$ concentrations of $E 600$ in $0.2 \mathrm{M}$-acetate buffer ( $\mathrm{pH} 5.5$ ) was also examined. Appropriate controls included the omission of substrate and of lead nitrate.

Acid deoxyribonuclease II. Attempts were made to investigate the distribution of this enzyme in fixed material by using the method of Vorbrodt (I96I). Difficulties were encountered with the method owing to the non-specific deposition of lead salts in localized areas. Investigation showed such non-specific lead staining over wide ranges of $\mathrm{pH}$ values, lead nitrate and buffer concentrations with incubation for more than $45 \mathrm{~min}$. at $37^{\circ}$. A modification of the Vorbrodt incubation medium was eventually used in which $0.3 \mathrm{ml}$. lead nitrate (0.I M) was used in $50 \mathrm{ml}$. medium. Unpolymerized calf thymus deoxyribonucleic $\mathrm{Na}$ salt (British Drug Houses) and acid phosphatase from wheat germ, 0. I 5 E.U./mg. (British Drug Houses) were used at the concentrations suggested by Vorbrodt. Incubation was for $\mathrm{I} \mathrm{hr}$ at $37^{\circ}$ followed by washing in water for I min., I \% (w/v) acetic acid for 2 min., development in ammonium sulphide solution for $2 \mathrm{~min}$. Controls included: (i) omission of substrate, (ii) omission of acid phosphatase, (iii) medium consisting of buffer containing lead nitrate, (iv) complete medium containing $0 \cdot \mathrm{I} \mathrm{M}-\mathrm{NaF}$ to judge the contribution towards the staining reaction of the non-specific lead localization.

Double staining methods. These involved the Gomori and standard coupling methods 
for acid phosphatase, the indoxyl method for esterase and the procedure for deoxyribonuclease II (DNase II), in techniques where staining was first done by one method, followed by subsequent staining by a second method for another hydrolase, to determine whether a single particle contained one or more enzyme types.

Aryl sulphatase. The distribution of this enzyme (or a non-specific esterase) was determined in fresh and fixed materials by using the method of Rutenberg, Cohen \& Seligman (1952) with a substrate of potassium 6-bromo-2-naphthylsulphate and coupling with Fast blue B salt at $0-4^{\circ}$. A simultaneous coupling procedure was also done with naphthol-AS sulphate in $0.1 \mathrm{M}$ phosphate buffer $\left(\mathrm{pH} \mathrm{6.2)}\right.$ at $37^{\circ}$, coupled with Fast red TR salt (G. T. Gurr, Ltd.).

$\beta-D$-glucuronidase. Attempts to show the activity of this enzyme in fixed tissues ( $2 \mathrm{hr}$ in cold neutral formalin) were unsuccessful. The substrates used were 8-hydroxyquinoline- $\beta$-D-glucuronide coupled with Fast blue RR salt (British Drug Houses) according to Pearse (I960) and 6-bromo-2-naphthyl- $\beta$-D-glucuronide coupled with Fast blue B salt (Seligman, Tsou, Rutenberg \& Cohen, I954), with incubation up to I $6 \mathrm{hr}$. Unfixed tissues were similarly examined.

$\beta$-Galactosidase was localized by using a substrate of 6-bromo-2-naphthyl- $\beta$-Dgalactopyranoside and incubation for $20 \mathrm{~min}$. at $37^{\circ}$ followed by post coupling to Fast blue B salt at $4^{\circ}$ (Rutenberg et al. 1958).

\section{RESULTS}

\section{Localization of acid phosphatase activity}

Fresh material was incubated in the Gomori test and control media and samples taken at intervals were examined for the presence of acid phosphatase activity. Localization of the reaction occurred in discrete sites within the cytoplasm $0 \cdot 2-\mathrm{I} \cdot 0 \mu$ in diameter and present in variable numbers (Pl. I, fig. I). The results are summarized in Table I. Staining in control sections did not occur except in lead nitrate + buffer

Table I. Staining reaction for acid phosphatase in Botrytis cinerea following incubation in Gomori medium at $37^{\circ}$

\begin{tabular}{ccccc}
$\begin{array}{c}\text { Incubation } \\
\text { time } \\
\text { (min.) }\end{array}$ & $\overbrace{\text { Particulate }}^{\text {Cytoplasmic }}$ & Diffuse & Nuclei & Controls \\
3 & 0 & 0 & 0 & 0 \\
7 & 0 & \pm & 0 & 0 \\
12 & \pm & \pm & 0 & 0 \\
24 & + & + & 0 & 0 \\
36 & \pm & + & \pm & 0 \\
48 & \pm & + & + & \pm \\
60 & \pm & + & + & + \\
\multicolumn{5}{l}{$+0=$ no reaction. }
\end{tabular}

controls and in sodium fluoride controls after $45 \mathrm{~min}$. incubation. Similar results were obtained with tissues placed in $5 \%$ polyvinyl alcohol for $15 \mathrm{~min}$. before staining. This treatment resulted in sharper particulate localization with decreased diffuse staining at the shorter incubation times.

Fresh tissues which had been fixed for $\mathrm{I} \mathrm{hr}$ at $4^{\circ}$ in $4 \%$ (w/v) aqueous formaldehyde solution, and fresh tissues pre-incubated in $0.05 \mathrm{M}$-acetate buffer $\left(\mathrm{pH} 5^{\circ} \mathrm{O}\right)$ at $37^{\circ}$ for 
$15 \mathrm{~min}$. before transfer to the test media became stained after a very brief incubation. Tissues which had been fixed in cold $4 \%$ neutral formalin for $\mathrm{I} \mathrm{hr}$ and then incubated in $0.25 \%(\mathrm{w} / \mathrm{v})$ aqueous Triton X-I00 before prolonged incubation in the control media showed no reaction (Table 2). Prolonged incubation of sections in the test medium resulted in staining outside the particulate sites when the cytoplasm took on diffuse stain with ultimate nuclear staining.

Table 2. Effects of pre-treatments upon localization of acid phosphatase in Botrytis cinerea using the Gomori procedure at $37^{\circ}$

\begin{tabular}{|c|c|c|c|c|c|c|c|}
\hline \multirow{3}{*}{ Treatment } & \multirow{3}{*}{$\begin{array}{l}\text { Staining } \\
\text { reaction }\end{array}$} & \multicolumn{6}{|c|}{ Incubation time (min.) } \\
\hline & & 2 & 5 & IO & 20 & 40 & 60 \\
\hline & & \multicolumn{6}{|c|}{ Reaction } \\
\hline \multirow{4}{*}{ Triton X-100 } & Particulate & 0 & 0 & 0 & 0 & 0 & 0 \\
\hline & Diffuse & 0 & 0 & 0 & 0 & 0 & 0 \\
\hline & Nuclear & $\circ$ & 0 & 0 & 0 & 0 & 0 \\
\hline & Particulate & \pm & + & + & + & \pm & \pm \\
\hline \multirow{2}{*}{$4 \%(w / v)$ aqueous formaldehyde } & Diffuse & 0 & \pm & + & + & + & + \\
\hline & Nuclear & 0 & \pm & + & + & + & + \\
\hline \multirow[t]{3}{*}{$0.05 \mathrm{M}$-acetate buffer $\mathrm{pH} 5.0$} & Particulate & \pm & + & + & \pm & \pm & \pm \\
\hline & Diffuse & 0 & \pm & + & + & + & + \\
\hline & Nuclear & 0 & \pm & + & + & + & + \\
\hline
\end{tabular}

The standard coupling (PI. I, fig. 2) and the post-coupling azo dye methods gave a particulate localization of acid phosphatase activity like that revealed by the Gomori procedure. These particles had the same size and distribution as those shown by the lead method; controls were unstained. As with the Gomori method prolonged incubation resulted in diffuse staining of the cytoplasm; nuclear staining was not detected. The presence of polyvinyl pyrrolidone in the test medium in the standard azo dye method resulted in decreased diffuse staining and sharper particle delimitation.

\section{Distribution of esterase activity}

Excellent particulate localization of esterase activity was revealed by the indoxyl method in tissues fixed for $16 \mathrm{hr}$ in cold formol + calcium fixative(Pl. 2, fig. 3). Incubation for longer periods than the optimum time of $30 \mathrm{~min}$. resulted in an intensification of the staining with gradual development of diffuse staining. Short periods of fixation, e.g. $2 \mathrm{hr}$, gave heavy diffuse staining after $\mathrm{I} \mathrm{hr}$ of incubation which tended to obscure particulate staining.

Pre-incubation of tissues in $1 \mathrm{I}^{-9}$ and $\mathrm{IO}^{-7} \mathrm{M}$ solutions of $E 600$ did not affect staining. Some decrease of diffuse staining was obtained in the presence of $1 \mathrm{O}^{-5} \mathrm{M}-E 600$; particulate staining was unaffected. Diffuse staining was completely suppressed at $10^{-3} \mathrm{M}-E 600$ with slight decrease in particulate staining. Controls for the inhibitor studies were pre-incubated in buffer alone, since Holt (1963) considered that washing of sections before incubation removed the enzyme responsible for the staining reaction. These controls showed slightly diminished staining. Iodoacetamide and $N$-ethylmaleimide did not influence staining at the concentrations used in these experiments. Controls in all test media were unstained. 
When fresh tissues were incubated for $5 \mathrm{~min}$. with $\alpha$-naphthylacetate in the presence of Fast blue B salt at $4^{\circ}$, dark blue diffuse staining of the cytoplasm was produced with darker particulate localization. The use of 'hexazotized' $p$-rosaniline as the coupling dye under similar conditions resulted in a dark-red diffuse cytoplasmic distribution of the stain so intense as to obscure any possible particulate localization. When the above methods were applied to fixed tissues, diffuse staining was decreased and particulate staining was readily visible (Pl. 2, fig. 4). Controls which excluded the substrates, dyes, or both were unstained.

Pre-incubation for $\mathrm{I}$ hr at $0^{\circ}$ in $10^{-5}$ and $10^{-6} \mathrm{M}-E 600$ in $0 \cdot \mathrm{I}$ M-phosphate buffer $(\mathrm{pH} 7 \cdot 4)$ suppressed particulate staining and greatly decreased diffuse cytoplasmic staining.

Staining did not occur with naphthol-AS acetate as a substrate in the presence of Fast red TR salt. However, coupling with 'hexazotized' $p$-rosaniline in fresh material resulted in dark-red diffuse cytoplasmic staining; but fixed tissues gave only a slight diffuse reaction. Particulate localization was not shown by any method utilizing naphthol-AS acetate. Controls gave negative results.

Fixed tissues incubated for $3 \mathrm{hr}$ at $22^{\circ}$ in the thioacetic acid medium gave excellent particulate localization of esterase activity (Pl. 2, fig. 5). Prolonged incubation resulted in the gradual intensification of diffuse cytoplasmic staining. Similar results were obtained with unfixed tissue, but development of diffuse staining was quicker and more intense. Pre-incubation in $10^{-9} \mathrm{M}-E 600$ had no inhibitory effect on staining. Concentrations of $E 600$ of $\mathrm{IO}^{-7}$ and $\mathrm{IO}^{-5} \mathrm{M}$ almost prevented diffuse cytoplasmic staining without affecting particulate staining. A concentration of $10^{-3} \mathrm{M}-E 600$ eliminated diffuse staining and decreased particulate staining; but on prolonged incubation the intensity of staining at particulate reaction sites gradually increased. The particulate localization obtained for esterases by the above methods was similar in size and distribution to that obtained for acid phosphatase.

\section{Acid deoxyribonuclease II localization}

Difficulties were experienced in using this method because of patchy non-specific lead staining which occurred at the optimum incubation time of $\mathrm{I}$ hr. These difficulties were overcome to some extent by using very low lead nitrate concentrations in the test media and by using adequate controls of lead nitrate + buffer solutions and complete media containing $O \cdot I \mathrm{M}-\mathrm{NaF}$. The extent of DNase activity was then assessed by comparison with the control tissues. Although patchy non-specific lead staining was seen in controls this was in contrast to the even staining which occurred at particulate reaction sites through DNase activity. All tests were done on tissues fixed for $16 \mathrm{hr}$ in cold formol + calcium fixative (P1. 2, fig. 6). Incubation for longer than $\mathrm{I}$ hr resulted in heavy diffuse staining.

\section{Detection of other hydrolases}

Aryl sulphatase. Fresh material incubated in the presence of 6-bromo-2-naphthylsulphate by the method of Rutenberg et al. (1958) for $3 \mathrm{hr}$ gave a very pale blue particulate localization of the stain. The simultaneous coupling method resulted in a pale brown diffuse cytoplasmic staining with a slightly darker red-brown particulate staining after incubation for $1.5 \mathrm{hr}$ at $37^{\circ}$; longer incubation resulted in flocculation 
of the diazonium reagent. Controls from which substrate was omitted gave no reactions.

$\beta$-D-glucuronidase. Attempts to localize sites of activity of this enzyme were unsuccessful.

$\beta$-Galactosidase. Dark blue particulate staining was seen after incubation of fresh material for $20 \mathrm{~min}$. at $37^{\circ}$ or $30 \mathrm{~min}$. at $25^{\circ}$. These particles had a similar size and distribution to those found to contain other hydrolases. A considerable degree of pink diffuse cytoplasmic staining also occurred which intensified with increasing incubation time, and after $\mathrm{I} \mathrm{hr}$ obscured particulate reaction sites. Material previously fixed for $2 \mathrm{hr}$ in cold formol + calcium showed more intense diffuse staining and fewer particulate sites of activity.

\section{Double stainirg methods}

Of the combinations of staining methods used the most successful were those in which fixed material previously stained for acid phosphatase activity by the Gomori or standard coupling azo dye methods was subsequently subjected to the indoxyl procedure for esterase localization. The use of the indoxyl method as the second procedure was particularly useful since the gradual double staining at room temperature could be observed with the microscope to give ultimately black particles. Such methods clearly showed that a proportion of particles present in the cytoplasm gave positive reactions for acid phosphatase and esterase. Similarly, staining of acid phosphatasecontaining particles by the standard coupling azo dye method followed by staining for DNase activity resulted in a certain proportion of the particles becoming doubly stained. Similar results were obtained with a combination of DNase and indoxyl staining methods. A small number of particles previously stained for esterase activity by the indoxyl method became stained with non-specific lead deposits when incubated for $\mathbf{I}-\mathbf{2} \mathrm{hr}$ in lead nitrate + buffer control solutions.

\section{DISCUSSION}

The latency of the acid phosphatase activity within the cytoplasmic particles, detected by use of the Gomori lead salt procedure, suggests a similarity between such particles and the lysosomes of animal cells as defined by de Duve (I959), and the lysosome-like particles of plant cells (Gahan, 1965). Also the Triton X-Ioo effect supports this view since it is generally assumed that this detergent disrupts the lipidprotein membrane of lysosomes, thus liberating the enzymes into the surrounding medium. The diffuse cytoplasmic staining following prolonged incubation is possibly a result of diffusion of the lead phosphate reaction product (Danielli, 1953). On the other hand, such diffuse staining might be due to the activity of other enzymes in the cytoplasm which are capable of a slower utilization of the $\beta$-glycerophosphate substrate and which are resistant to NaF inhibition (Gahan, 1965), or to non-specific lead staining. That some contribution to such staining arises from the latter is supported by the findings of heavy lead deposition in the controls incubated for periods longer than $60 \mathrm{~min}$. The occasional particulate nature of this staining was similar to that found with the lysosome-like particles except that it was not affected by $\mathrm{NaF}$. However, results with the Gomori method were not invalidated by such staining since the optimum reaction time for the method never exceeded $30 \mathrm{~min}$., by which time non-specific lead deposits were negligible. The excellent particulate: 
localization of acid phosphatase activity made visible by the azo dye methods was free from the possible criticism associated with the Gomori procedure and confirmed the existence and nature of the localized activity of the enzyme.

The demonstration of carboxylic esterase activity which was achieved by several methods, and the response to formalin fixatives and specific enzyme inhibitors, indicated a situation as complex as that found with animal tissues (Holt, 1963). Hess \& Pearse (1958) suggested that the esterase activity revealed by the indoxyl method is due to the activity of cathepsin $C$. The indoxyl esterase in the present work, however, was resistant to $10^{-3} \mathrm{M}-E 600$ and to iodoacetamide and $N$-ethylmaleimide. If one accepts the argument of Holt ( 1963 ) concerning inhibition of cathepsin activity it is apparent that this enzyme in Botrytis cinerea is neither cathepsin B, C nor D, and in these respects is similar to the indoxyl esterase investigated in mammalian tissues by Holt, the nature of which is currently unknown. The inhibition of particulate staining by $E 600$ in the $\alpha$-naphthylacetate $p$-rosaniline method might indicate the presence of an organophosphorus-sensitive esterase (possibly of type B similar to that found by Müller (I962), in Paramecium). But the inhibitor studies made in the present work do not allow complete characterization of the esterases so far detected.

In spite of various modifications to the Vorbrodt (I96I) method for acid DNase II activity this method was not found so suitable for fungal histochemistry in the present work as it has been with animal tissues. With appropriate controls some evidence was obtained for the existence of this enzyme within the fungal cytoplasmic granules, and the double-staining methods showed that acid phosphatase, indoxyl esterase and DNase II were located within the same particles. However, only a proportion of such particles were seen to be double-stained.

The staining for aryl sulphatase activity was very weak in contrast to the speed and intensity of reaction reported by Avers (196I) in grass roots. Prolonged incubation at high temperature, found necessary in the present work, may have resulted in false localization, since according to Pearse (1960) the reaction products are lipid-soluble and liable to diffuse. In the absence of biochemical evidence for the existence of aryl sulphatase in fungi and because of the limitations of present histochemical methods the evidence for its particulate localization in Botrytis cinerea is weak.

The localization of some activity of $\beta$-galactosidase within cytoplasmic particles is consistent with the observations of Zalokar (1960) who obtained localization of this enzyme in the mitochondrial fraction of freeze-substituted centrifuged cells of Neurospora. The failure to detect $\beta$-D-glucuronidase activity does not necessarily mean the absence of this enzyme, but Avers (I96I), using similar methods, also failed to detect this enzyme in higher-plant tissues.

The present work has shown the localization of activities of several hydrolytic enzymes within cytoplasmic particles of Botrytis cinerea which have some features in common with the lysosomes of animal cells. Other important lysosomal enzymes sought in Botrytis cinerea showed only weak activity or were not detected by methods successfully employed for their detection in animal tissues.

The generous gift of Triton X-I0o from Lennig Chemicals Ltd., 26-28 Bedford Row, London, is gratefully acknowledged. 


\section{REFERENCES}

Avers, C. J. (I96I). Histochemical localization of enzyme activities in root meristem cells. Am. J. Bot. 48, 137.

Danielli, J. F. (I953). Cytochemistry. London: Chapman and Hall.

Davis, B. J. \& ORNSTEIN, L. (1959). High resolution enzyme localization with a new diazo reagent, 'hexazonium pararosaniline'. J. Histochem. Cytochem. 7, 297.

DE DUVE, C. (1959). Lysosomes, a new group of cytoplasmic particles. In Subcellular Particles. Ed. by T. Hayashi. P. I28. New York: Ronald Press.

Gahan, P. B. (1965). Histochemical evidence for the presence of lysosome-like particles in root meristem cells of Vicia faba. J. exp. Bot. 16, 350.

Gomori, G. (1952). Acid Phosphatase. In Microscopic Histochemistry. P. 189. University of Chicago Press.

Grogg, E. \& Pearse, A. G. E. (1952). A critical study of the histochemical techniques for acid phosphatase with a description of an azo dye method. J. Path. Bact. 64, 627.

Hess, R. \& Pearse, A. G. E. (1958). The histochemistry of indoxylesterase of rat kidney with special reference to its cathepsin-like activity. Br. J. exp. Path. 39, 292.

Holt, S. J. (1958). In General Cytochemical Methods. Ed. by J. F. Danielli. Vol. I, p. 375. New York: Academic Press.

Holt, S. J. (I963). Some observations on the occurrence and nature of esterases in lysosomes. In The Lysosomes Ed. by A. V. S. de Reuck and M. P. Cameron. P. I I4. London: J. and A. Churchill Ltd.

MÜLLER, M. (I962). Studies on feeding and digestion in protozoa. V. Demonstration of some phosphatases and esterases in Paramecium multimicronucleatum by histochemical methods. Acta biol. hung. 13, 283.

Nachlas, M. M. \& Seligman, A. M. (1949). The comparative distribution of esterase in the tissues of five mammals by histochemical technique. Anat. Rec. ro5, 677 .

Novikoff, A. B. (196I). Lysosomes and related particles. In The Cell. Ed. by J. Brachet and A. E. Mirsky, Vol. 2, p. 423. New York and London: Academic Press.

Pearse, A. G. E. (1960) Histochemistry, Theoretical and Applied. London: J. and A. Churchill Ltd.

PIrT, D. \& WALKER, P. J. (1967). Particulate localization of acid phosphatase in fungi. Nature, Lond. 215, 783 .

RIDELL, R. W. (1950). Permanent stained mycological preparations obtained by slide culture. Mycologia 42, 265.

Rutenberg, A. M. \& Seligman, A. M. (1955). The histochemical demonstration of acid phosphatase by a post-incubation coupling technique. J. Histochem. Cytochem. 3, 455 .

Rutenberg, A. M., Cohen, R. B. \& Seligman, A. M. (1952). Histochemical demonstration of aryl sulphatase. Science, N.Y. xI6, 539.

Rutenberg, A. M., Rutenberg, S. H., Monis, B., Teague, R. \& Seligman, A. M. (I958). Histochemical demonstration of $\beta$-D-galactosidase in the rat. J. Histochem. Cytochem. 6, 122.

Seligman, A. M., Tsou, K. C., Rutenberg, S. H. \& Cohen, R. B. (1954). Histochemical demonstration of $\beta$-D-glucuronidase with a synthetic substrate. J. Histochem. Cytochem. 2, 209.

VORBRODT, A. (196I). Histochemical studies on the intracellular localization of acid deoxyribonuclease. J. Histochem. Cytochem. 9, 647.

Wachstein, M., Meisel, E. \& Falcon, C. (I96I). Histochemistry of thiolacetic acid esterase: a comparison with non-specific esterase with special regard to the effect of fixatives and inhibitors on intracellular localization. J. Histochem. Cytochem. 9, 325.

ZaLOKAR, M. (1960). Cytochemistry of centrifuged hyphae of Neurospora. Exp. Cell Res. 19, II4.

\section{EXPLANATION OF PLATES}

Particulate localization of hydrolases in Botrytis cinerea.

\section{Plate I}

Fig. I. Particles containing acid phosphatase revealed by the Gomori lead salt method. $\times$ I 827 .

Fig. 2. Acid phosphatase particles, standard coupling azo dye method. $\times 1370$. 
Journal of General Microbiology, Vol. 52, No. I Plate I

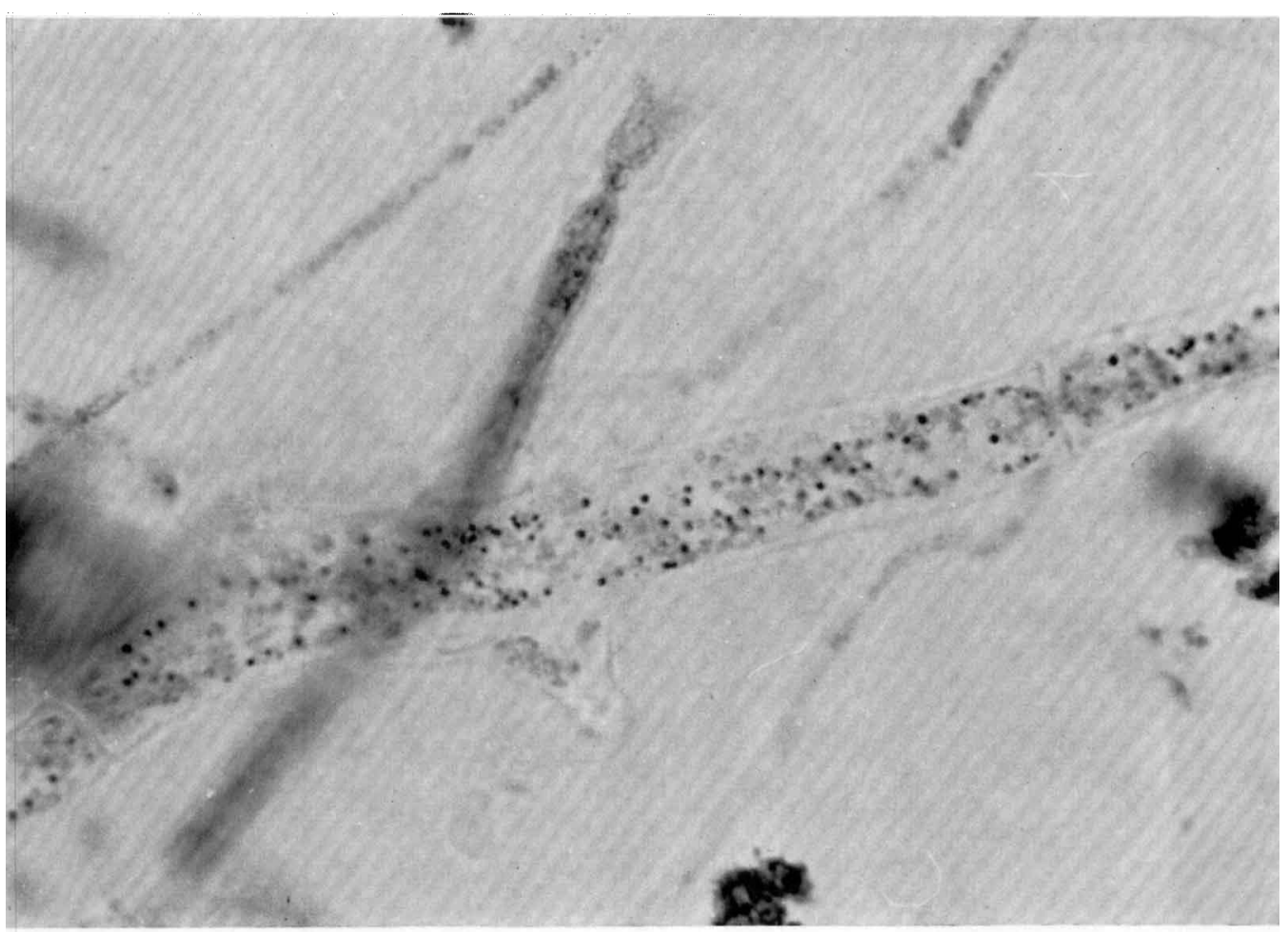

Fig. I

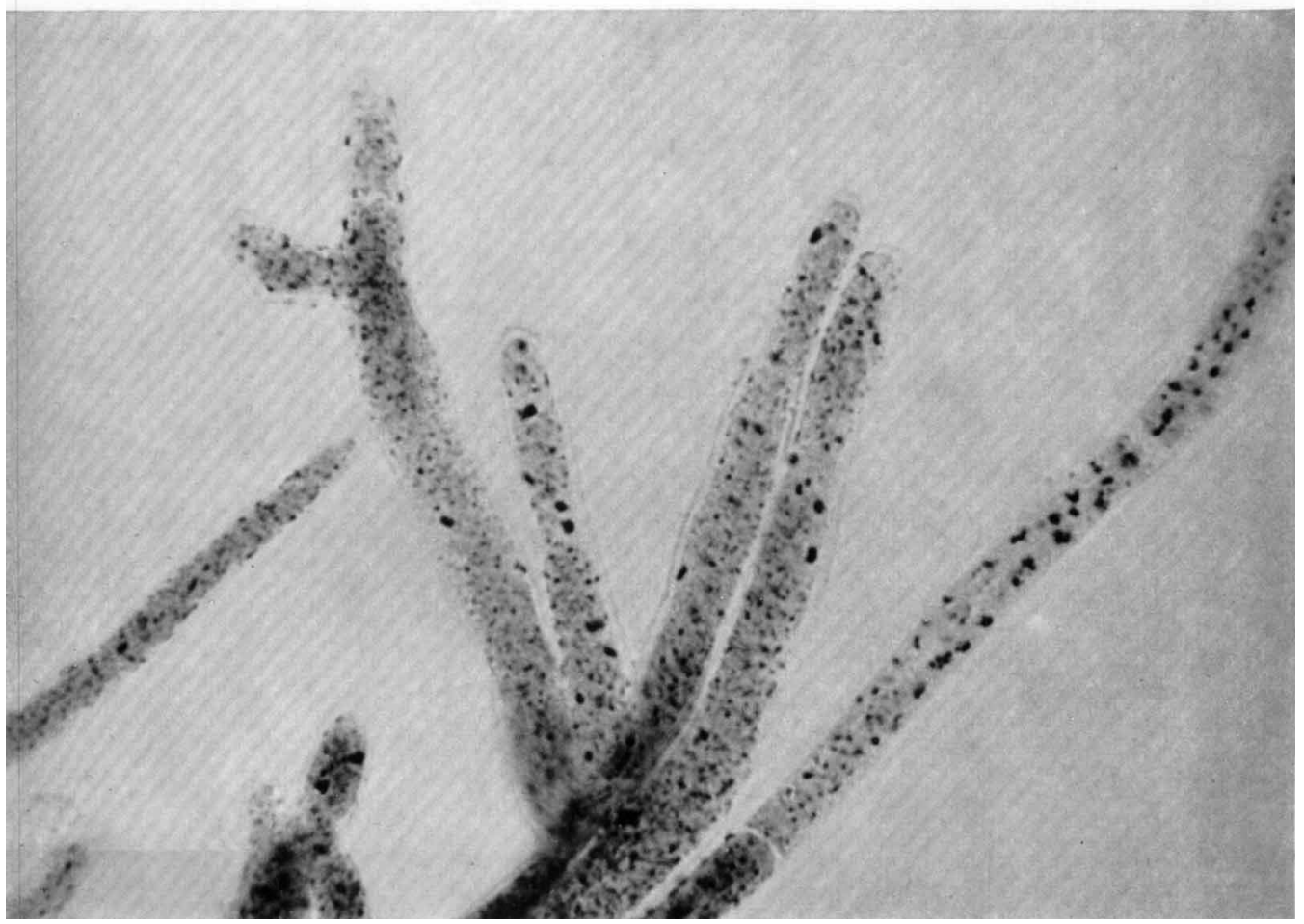

Fig. 2 
Journal of General Microbiology, Vol. 52, No. I

Plate 2

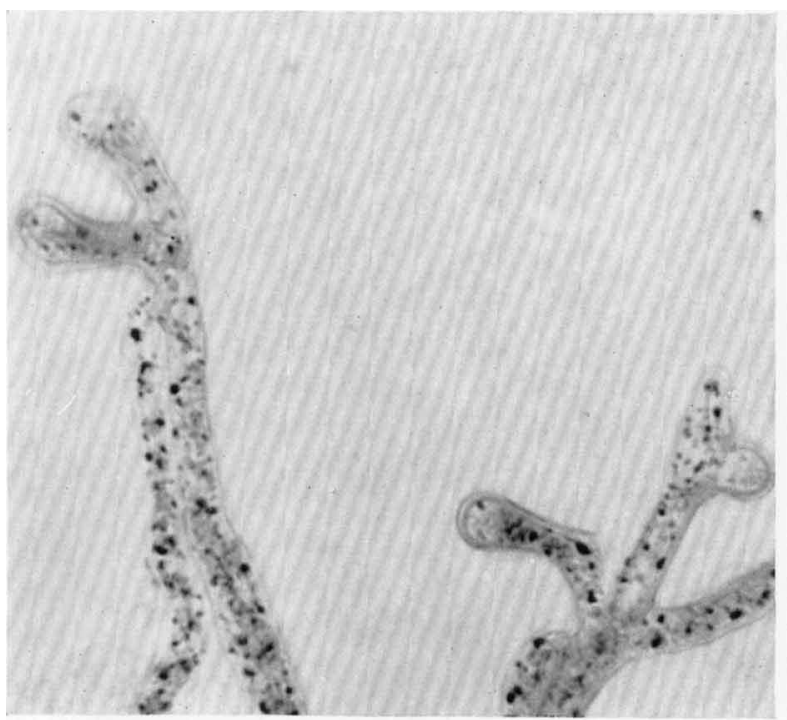

Fig. 3

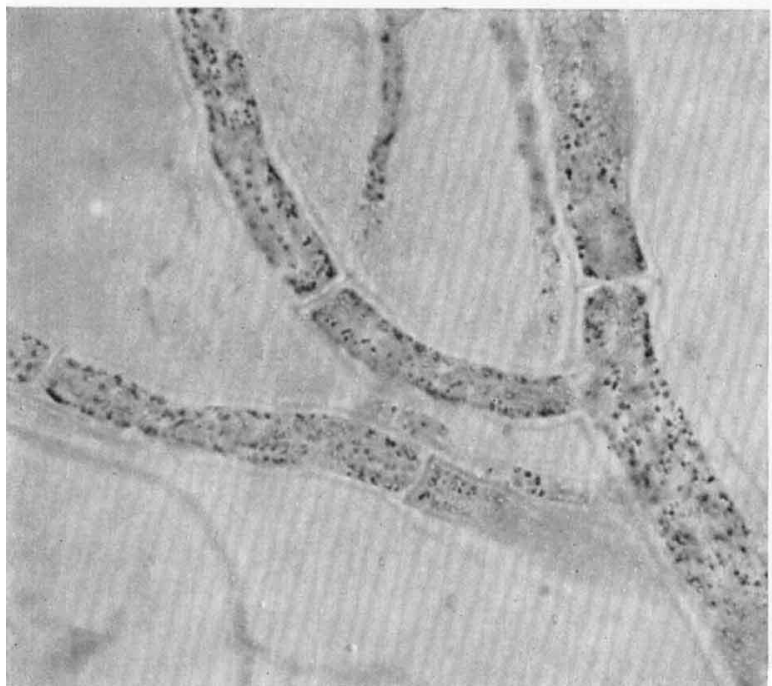

Fig. 5

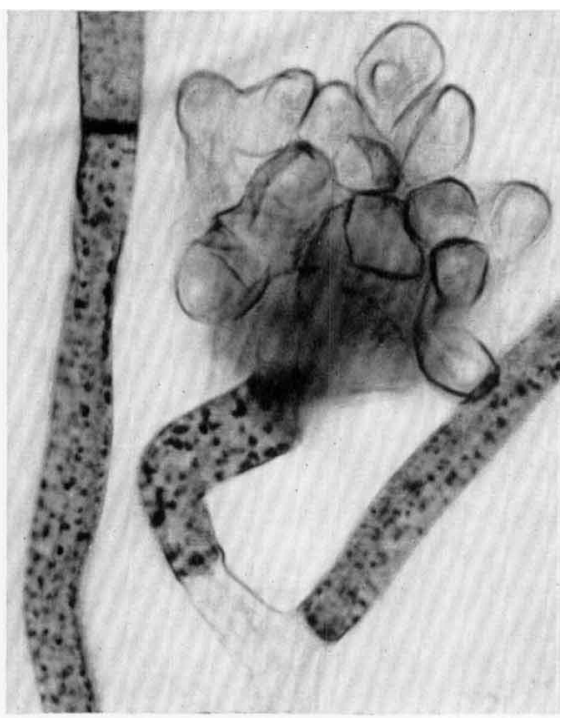

Fig. 4

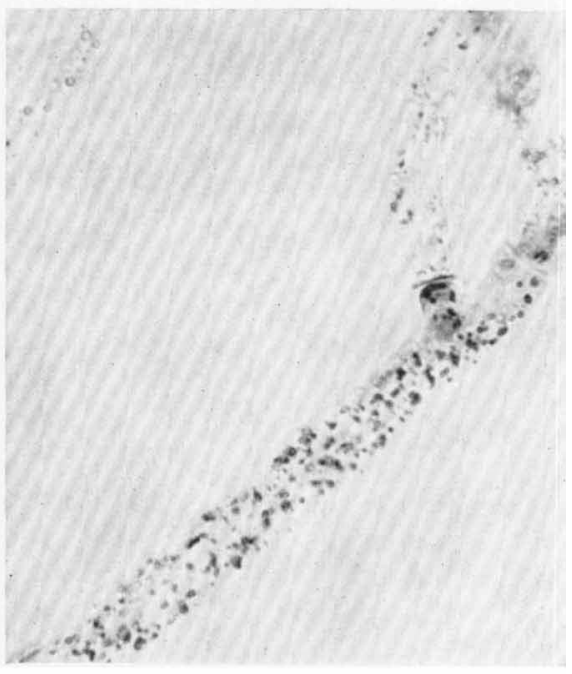

Fig. 6 


\section{Plate 2}

Fig. 3. Esterase activity made visible by the indoxyl method. $\times 1027$.

Fig. 4. Particulate localization of esterase by the $\alpha$-naphthylacetate + 'hexazotized' $p$-rosaniline method. $\times 1027$.

Fig. 5. Esterase activity localized by the thioacetic acid procedure. $\times 1198$.

Fig. 6. Particulate localization of DNase activity by the Vorbrodt (1961) method. $\times 1198$. 